\title{
Biflorin: an o-naphthoquinone of clinical significance
}

\author{
GABRIELLE G.N.S. WISINTAINER ${ }^{1}$, EVELYNE R.B. SIMÕES ${ }^{3}$, TELMA L.G. LEMOS ${ }^{4}$, \\ SIDNEI MOURA ${ }^{2}$, LUCIANA G.S. SOUZA ${ }^{4}$, ALUISIO M. FONSECA ${ }^{6}$, MANOEL ODORICO MORAES ${ }^{5}$, \\ CLAUDIA PESSOA $^{3}$, MARIANA ROESCH-ELY ${ }^{1}$ and JOÃO A.P. HENRIQUES ${ }^{1}$ \\ ${ }^{1}$ Laboratório de Genômica, Proteômica e Reparo de DNA, Instituto de Biotecnologia, \\ Universidade de Caxias do Sul, Rua Francisco Getúlio Vargas, 1130, 95070-560 Caxias do Sul, RS, Brasil \\ ${ }^{2}$ Laboratório de Biotecnologia de Produtos Naturais e Sintéticos, Instituto de Biotecnologia, \\ Universidade de Caxias do Sul, Rua Francisco Getúlio Vargas, 1130, 95070-560 Caxias do Sul, RS, Brasil \\ ${ }^{3}$ Laboratório de Oncologia Experimental, Departamento de Fisiologia e Farmacologia, Faculdade de Medicina, \\ Universidade Federal do Ceará, Caixa Postal 3157, 60430-270 Fortaleza, CE, Brasil \\ ${ }^{4}$ Departamento de Química Orgânica e Inorgânica, Universidade Federal do Ceará, \\ Caixa Postal 12200, 60021-940 Fortaleza, CE, Brasil \\ ${ }^{5}$ Departamento de Fisiologia e Farmacologia, Universidade Federal do Ceará, \\ Rua Cel. Nunes de Melo, 1127, 60430-270 Fortaleza, CE, Brasil \\ ${ }^{6}$ Instituto de Ciências Exatas e da Natureza/ICEN, Campos dos Palmares, Universidade da Integração \\ Internacional da Lusofonia Afro-Brasileira, Rodovia CE 060, Km 51, 62785-000 Acarape, CE, Brasil \\ Manuscript received on February 12, 2014; accepted for publication on August 7, 2014
}

\begin{abstract}
Biflorin is an $o$-naphthoquinone with proven cytotoxic effects on tumor cells showing antimicrobial, antitumor and antimutagenic activities. Biflorin is an isolated compound taken from the roots of the plant Capraria biflora L. (Schrophulariaceae), indigenous of the West Indies and South America, which is located in temperate or tropical areas. This compound has shown to be strongly active against grampositive and alcohol-acid-resistant bacteria. It has been efficient in inhibiting the proliferation tumor cell lines CEM, HL-60, B16, HCT-8 and MCF-7. Recently, SK-Br3 cell line was treated with biflorin showing important cytotoxic effects. In this article, information related to the first structural characterization studies are presented, as well as the latest reports concerning the biological activity of this molecule.
\end{abstract}

Key words: biological activity, Biflorin, Capraria biflora, natural products.

\section{INTRODUCTION}

Natural products are the largest contributor to the production of active metabolites, and many of them are used as drugs, cosmetics and pesticides (Mann 2002). They do not always contribute in an integral manner to the synthesis of drugs; however, occasionally serve as models for the synthesis of new

Correspondence to: João Antonio Pêgas Henriques

E-mail:pegas@cbiot.ufrgs.br drugs, such as procaine, chloroquine, vincristine, vinblastine and camptothecin (Newman et al. 2003, Ferreira et al. 2010).

Products of natural origin play an important role in the treatment and prevention of human diseases, and over $60 \%$ of drugs used have natural origins. Among the sources of such drugs found in nature, plants provide the largest contribution to the development of therapeutic substances (Kirkpatrick 
2002, Silva 2006, Costa-Lotufo et al. 2010). Among new drugs launched between 1981 and 2002 in the pharmaceutical market, $28 \%$ are made from natural products, and $24 \%$ are synthetic derivatives of natural origin, which emphasizes the importance of studies in this area (Gullo et al. 2006). Drugs derived from natural sources have anti-cancer, antimicrobial and antiviral activity (Silva 2006). More than 100 compounds derived from natural products are undergoing clinical trials (Harvey 2008).

The study of medicinal plants allowed the discovery of several molecules for the treatment of cancer, such as the alkaloids vinblastine and vincristine, both isolated from Catharanthus roseus $G$., which are used for lymphomas and acute leukemias, respectively. These drugs also served as the basis for the semisynthetic derivatives vindesine, which is used for acute lymphoblastic leukemia, and vinorelbine, used for lung and breast cancer (Cragg and Newman 2005, Newman and Cragg 2007, Silva 2006).

For the last decades, an o-naphthoquinone isolated from Capraria biflora L., biflorin, has shown promising biological activities against several organisms. Only more recently, this quinone began to play an important role related to tumor development and progression, where several reports using in vitro and in vivo investigations were published.

NATURAL SOURCES OF BIFLORIN

Capraria biflora $L$. is a plant that belongs to the Schrophulariaceae family, originates from the Antilles and South America and inhabits temperate or tropical areas (Aquino et al. 2006). As it is an invasive plant, found on wasteland, preferring humid, near-shore streams or ponds (Aquino et al. 2001). It is widely distributed in South America (Venezuela, Peru and Guyana), Central America (El Salvador, Trinidad and Tobago, Bahamas, Panama, Curacao, Guatemala and Puerto Rico), North America (United States and Mexico) and Asia (India and
China) (Correia 1984). In Brazil, it is located in the states of Minas Gerais and Goiás and in the coastal strip between Espirito Santo and Piauí (Aquino et al. 2006). Capraria biflora L. is an herbaceous plant or shrub whose stem is twiggy, reaching a height of $1.5 \mathrm{~m}$ (Aquino et al. 2001). It has been used to treat fever and given its diuretic, stimulant and digestive properties, also pointed as beneficial to digestion (Matos Brito et al. 1994). The aqueous extract has demonstrated both peripheral and central analgesic effects (Acosta et al. 2003). The roots of Capraria biflora L. yield biflorin, an o-naphthoquinone, to date the only substance isolated from this plant with proven medicinal activity (Aquino et al. 2006).

Biflorin has also been found in other plants apart from C. biflora L. In 2007, Ndi et al. reported the presence of biflorin in extracts of an Australian desert plant known as Eremophila neglecta. The family Myoporaceae is characterized by its large amount of potential secondary metabolites. To obtain compounds as biflorin, the authors performed a series of extractions with varying solvents (Ndi et al. 2007). The products were identified by ${ }^{1} \mathrm{H}$-and ${ }^{13} \mathrm{C}$ NMR. Previously, Forster et al. (1986) indicated the presence of naphthoquinone in plants of the same family, Eremophila latrobei (Forster et al. 1986).

Chemical Structure AND Biological ACTIVITy of QUINONES

The quinones are a large and important class of substances present in nature and can be obtained as a synthetic product with a great variety of applications (Thomson 1987). The quinone structure was identified as an important pharmacophore group and is characterized by a significant cytotoxic effect through several drugs used in treating diseases (Driscoll 1974, Liu et al. 2004), thus constituting a class of highly representative antineoplastic agents (Asche 2005).

Quinones are organic compounds produced by the oxidation of phenols, and its reduction also gives the corresponding phenols. Their hallmark 
is the presence of two carbonyl groups that form a conjugated system with at least two CC double bonds. Thus, according to the cycle in which the system of conjugated double and ketones is inserted, three major groups of quinones exist: benzoquinones have a benzene ring, naphthoquinones have a naphthalene ring and anthraquinones have an anthracene ring (Figure 1) (Simoes et al. 2001).

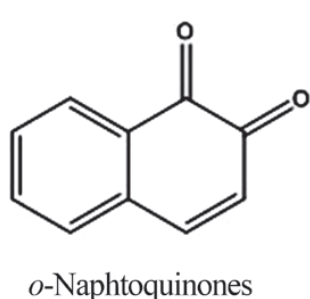

$o$-Naphtoquinones

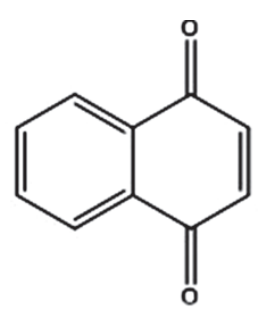

$p$-Naphtoquinones
Figure 1 - Isomeric forms of ortho-and para-quinonone.

Natural and synthetic compounds that have quinones in their structures are known to possess potent biological activities such as anticancer (Silva et al. 2003, Asche 2005), antimollusc (Santos et al. 2000, Barbosa et al. 2005), anti-leishmanial (Teixeira et al. 2001), antiinflammatory (Almeida et al. 1990), anti-fungal (Gafner et al. 1996), trypanocidal (Pinto et al. 2000, Moura et al. 2001), anti-protozoal (Zani et al. 1997), and anti-viral (Stagliano et al. 2006) activity. Anti-tumor agents are effective inhibitors of DNA topoisomerase I (Asche 2005). Thus, the interest in these substances has intensified in recent years because of their pharmacological importance. Some pharmacological activities are known for compounds such as $\beta$-lapachone, a natural substance that is easily obtained from lapachol, which is found as a minor constituent of the heartwood of trees of the family Bignoniaceae, known in Brazil as Ipe (Ferreira et al. 2010) (Figure 2). The $\beta$-lapachone, a potent trypanocidal agent, has shown cytotoxicity against tumor cells. Part of the mechanism of action of quinones involves the generation of reactive oxygen species (ROS), which have been shown to be toxic to Trypanosoma cruzi and induce apoptosis and / or interact with topoisomerase of tumor cells (Ferreira et al. 2010). Naphthoquinone is the most notable member of this class of substances because it is has been applied to phase II studies for the treatment of pancreatic cancer (Ferreira et al. 2010). $\beta$-lapachone has shown to be effective in vitro against various human malignant cell lines, including melanoma, leukemia, colorectal, lung, breast and prostate cancer cells (Ferreira et al. 2010).
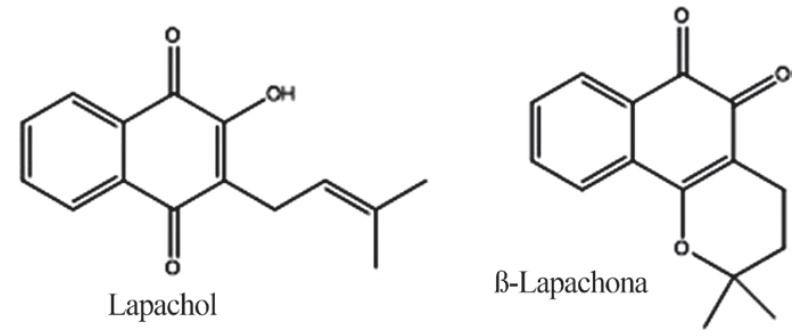

Figure 2 - Chemical structure of lapachol and $\beta$ - lapachone.

\section{BIFLORIN CHARACTERIZATION}

The first studies with phytochemicals from $C$. biflora $L$ were performed by Gonçalves de Lima et al. (1954), who isolated from the roots of the plant an active ingredient that showed antimicrobial activity against gram-positive, acid-resistant bacteria and some fungi (Gonçalves de Lima et al. 1954). This substance was termed biflorin, 6,9-dimethyl-3(4-methyl-3-pentenyl)naphtha[1,8-bc]pyran-7,8dione. In the same year, the spectrum of activity of biflorin was determined by Eli Lilly (Mc Cowen and Stone 1953). In the following year, a method for obtaining pure crystals of naphthoquinone was developed and these crystals presented higher activity against gram-positive bacteria when compared to the naphthoquinone used in the initial studies. Biflorin also showed activity against other microorganisms (dermatophytes and yeasts) not been previously tested (Gonçalves de Lima et al. 1954, 1958). In 1958, a method was developed with an even higher yield than the methods previously 
described. In the same year, the physical and chemical characteristics of biflorin were elucidated using the methods of UV (ultraviolet) and IR (infrared) spectroscopy and elemental analysis, in which the presence of a naftoquinonic structure was confirmed (Prelog et al. 1958, Comin et al. 1963, Grant et al. 1963).

The earliest studies on the chemical structure biflorin include the work of Hoppe (1960), who used crystallographic analysis with X-ray diffraction (Hoppe 1960) to determine the crystalline structure and structural formula $\mathrm{C}_{20} \mathrm{H}_{20} \mathrm{O}_{3}$. Fonseca et al. (2003), using ${ }^{1} \mathrm{H}$ and ${ }^{13} \mathrm{C}$ nuclear magnetic resonance in oneand two-dimension experiments, showed that biflorin naturally exists as a dimer that was named Bis-biflorin (Fonseca et al. 2003), as shown in Figure 3.

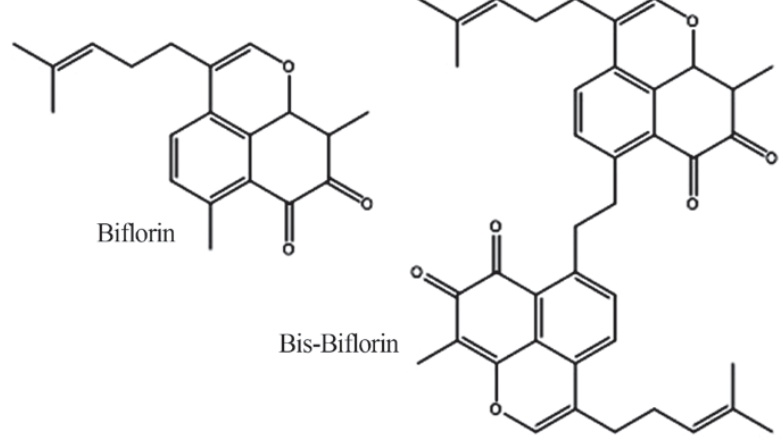

Figure 3 - Chemical structures of biflorin and bis-biflorin (Fonseca et al. 2003).

Gonçalves de Lima et al. (1961) demonstrated the photosensitivity of biflorin to natural light (Gonçalves de Lima et al. 1961, 1962). In more recent studies, new methods of quantification and qualification of the biflorin through liquid chromatography coupled to mass detection were evaluated and found to be fast and accurate (Lyra Jr et al. 2007).

\section{CHEMICAL SyNTHESIS}

Since the early nineteenth century, when the chemical structures of the first naphthoquinones were identified, researchers have been attempting the synthesis or semi-synthesis of these compounds
(Ehrlich and Herter 1904). Synthesis procedures as metathesis became easier for the formation of the condensed cycles that are part of the basic structure of these compounds (Song et al. 2009). The search for the synthesis of new structures target the enhancement of biological activity, and compounds such as fluoro-1,4-naphthoquinones were synthesized by Zakharova et al. (2011). Later, several natural naphthoquinones such as $\beta$-lapachone were also synthesized (Zakharova et al. 2011). The condensation reactions to produce a series of compounds were further tested according to their anti-inflammatory activity (Tseng et al. 2013).

Interestingly, only one total synthesis procedure for biflorin has been presented in the literature (Best et al. 1986), most likely because of the complex chemical structure of is compound. In this procedure, an addition-type intramolecular DielsAlder reaction was the key step for obtaining the final product, as shown in Figure 4.

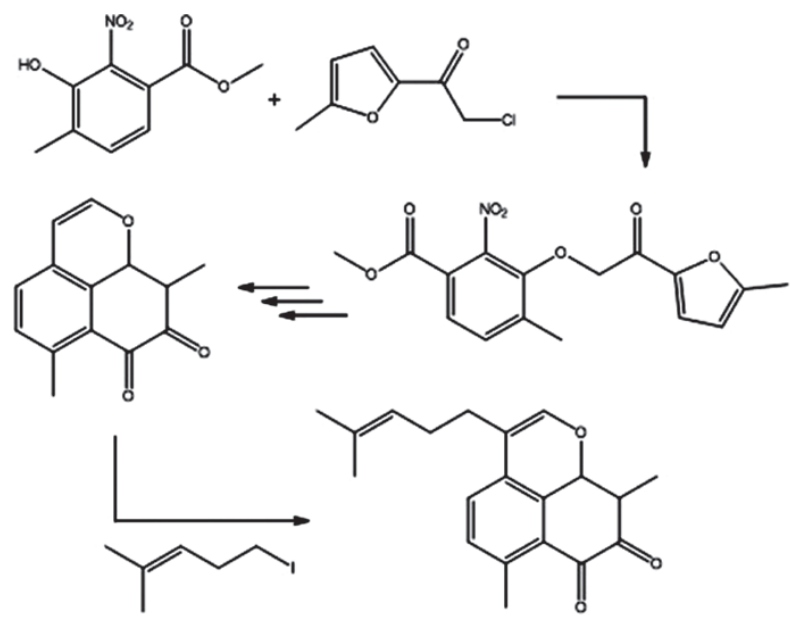

Figure 4 - Schematic representation of the chemical synthesis of biflorin presented by Best and Wege 1986.

Previously, Comin et al. (1963) obtained differentiated structures of biflorin through hydrogenation reactions. In a typical case of semi-synthesis, these authors described physicochemical properties of the products obtained by reaction of $1 \mathrm{~mol}$ of natural biflorin 
extracted from $C$. biflora with one and two equivalents of hydrogen. The hydrogenation products were subsequently acetylated and oxidized to yield the diacetate and prenitic acid, respectively (Comin et al. 1963).

\section{BIOLOGICAL ACTIVITY OF BIFLORIN}

Studies related to o-naphthoquinone began in 1999 and showed antimicrobial activity, mostly in strains of Candida albicans. Other bacteria were studied previously, and biflorin showed antimicrobial activity against gram-positive and gram-negative bacteria (Gonçalves de Lima et al. 1961).

The only clinical case reporting the use of biflorin was in 1958 , where $1 \%$ biflorin crystallized paste was used in a 14-year-old male patient with an erythematous perioral lesion covering the outside area of the lip. After sample collection in different areas, it was possible to isolate a fungus identified as Trichosporon margaritipherum. The patient began using $1 \%$ biflorin with lanolin and petrolatum, and after two days, the lesion showed a pink color with no exudation and the skin returned to normal after four days of treatment. The paste vehicle was later replaced by polyethylene glycol, which provided better results, and after a week, the erythema had completely recovered (Aquino et al. 2006).

Biflorin has in vivo and in vitro antitumor effects (Table I), but its exact mechanism of action is not yet known (Vasconcellos et al. 2005, 2007). This molecule has shown a concentrationdependent cytotoxic effect in different eukaryotic cells, but not mutagenic in bacteria and yeast (Vasconcellos et al. 2010).

The protective effects of biflorin against mutagenesis in yeasts and V79 cells occurred only at low concentrations; high concentration of biflorin (concentrations higher than $250 \mu \mathrm{g} / \mathrm{ml}$ in haploid yeast and $10 \mu \mathrm{g} / \mathrm{ml}$ in V79 cells) was cytotoxic, inducing breaks in the DNA chain as evidenced by the comet test (Vasconcellos et al. 2010). Another mechanism that leads to breaks in
TABLE I

Biological activities of biflorin shown in different studies.

\begin{tabular}{lll}
\hline Organisms & $\begin{array}{l}\text { Type of } \\
\text { activity }\end{array}$ & Reference \\
\hline $\begin{array}{l}\text { Trichosporon } \\
\text { margaritipherum }\end{array}$ & Antifungical & $\begin{array}{l}\text { Aquino } \\
\text { et al. 2006 }\end{array}$ \\
\hline $\begin{array}{l}\text { Gran-positive bacteria, } \\
\text { Bacteria alcohol-acid- } \\
\text { resistent }\end{array}$ & Antimicrobial & $\begin{array}{l}\text { Gonçalves de } \\
\text { Lima et al. } \\
1954\end{array}$ \\
\hline Candida albicans & Antimicrobial & $\begin{array}{l}\text { Lyra Junior } \\
\text { et al. 1999 }\end{array}$ \\
\hline $\begin{array}{l}\text { Yeast S. cereviseae } \\
\text { and V79 }\end{array}$ & Antimutagenic & $\begin{array}{l}\text { Vasconcellos } \\
\text { et al. 2010 }\end{array}$ \\
\hline $\begin{array}{l}\text { Cells V79 } \\
\text { Tumor cell lines CEM, HL-60, }\end{array}$ & Antitumor & $\begin{array}{l}\text { Vasconcellos } \\
\text { et al. 2010 }\end{array}$ \\
\hline B16, HCT-8 and MCF-7 & $\begin{array}{l}\text { Vasconcellos } \\
\text { et al. 2007 } \\
\text { Vasconcellos } \\
\text { et al. 2005 }\end{array}$ \\
\hline
\end{tabular}

the DNA chain is the interaction of the particles with DNA topoisomerase I (Vasconcellos et al. 2010). The induction of DNA damage by biflorin underlies its anti-proliferative potential (Vasconcellos et al. 2007). In the same study, it was demonstrated that biflorin does not induce frameshift mutations in yeast and bacteria; therefore, the authors assumed that biflorin is not a good DNA intercalating agent. However, other studies have shown that this molecule causes no changes in the cell cycle; rather, it inhibits the synthesis of DNA and interacts directly with singlestranded DNA and double-stranded DNA to induce cell death by apoptosis (Vasconcellos et al. 2007).

Antitumor activity in vivo was evaluated in animals transplanted with sarcoma 180 and Ehrlich carcinoma cells, showing promising antitumor activity with low toxicity on histopathological examination of the spleen, kidney and liver. Moreover, when coupled with 5-fluoracil chemotherapy (5-FU), biflorin increased the effectiveness in addition to reducing systemic toxicity (Vasconcellos et al. 2007). In experiments with animals transplanted with B16 melanoma cells, biflorin was administered at $25 \mathrm{mg}$ /day for 10 days, and there was a significant inhibition of tumor growth with no systemic toxicity (Vasconcellos et al. 2011). A metastasis assay 
performed by intravenous injection of B16-F10 cells (a cell line with high metastatic potential) in mice, a dose-dependent inhibitory effect of biflorin was observed against the formation of metastatic nodules in the lung tissue (Carvalho et al. 2013).

In a recent study, the SK-Br3 cell line (breast cancer) was treated with biflorin, and the results showed cytotoxicity against this line. Moreover, biflorin produced a decrease in the expression of EGFR (epidermal growth factor receptor), where inhibition of proliferation in biflorin-treated cells was shown to be mediated in part by down-regulation of the EGFR signaling pathway (Montenegro et al. 2013).

Biflorin has shown to present protective capacity against oxidative stress induced by $\mathrm{H}_{2} \mathrm{O}_{2}$ (hydrogen peroxide), as confirmed by the reduction of lipid peroxidation in V79 cells (Vasconcellos et al. 2010). Hydrogen peroxide is an important compound for ROS that, in combination with metals such as reduced iron or copper, is transformed by a Fenton reaction with the highly reactive hydroxyl radical $(\mathrm{OH} \bullet)$, which causes damage to practically all macromolecules (Halliwell and Gutteridge 2007). Thus, biflorin reduces DNA damage and mutation triggered by $\mathrm{H}_{2} \mathrm{O}_{2}$ in yeast $S$. cerevisiae and V79 cells, suggesting an anti-oxidant effect (Vasconcellos et al. 2010).

Montenegro et al. 2013 suggests a mechanism of action for biflorin in MDA-MB-435 melanoma cells, most likely by the inhibition of N-cadherin. In this report, inhibitors of $\mathrm{N}$-cadherin function have been demonstrated to cause apoptosis and regulate the AKT-1 pathway (Montenegro et al. 2013).

\section{CONCLUSIONS}

The chemical characteristics of biflorin were elucidated using the methods of UV (ultraviolet) and IR (infrared) spectroscopy and elemental analysis, in which the presence of a naphtoquinonic structure was confirmed. In different concentrations, the scavenging of hydroxyl radicals by biflorin may contribute to antioxidant activity and protective effects against cytotoxicity, genotoxicity, mutagenicity and intracellular lipid peroxidation induced by $\mathrm{H}_{2} \mathrm{O}_{2}$. Higher biflorin concentrations, however, are cytotoxic, possibly because of its ability to induce DNA strand breaks (Vasconcellos et al. 2010). Biflorin has numerous biological activities related to the regulation of apoptosis, the cell cycle and cell differentiation. Studies indicate that biflorin presents antioxidant activity and cytotoxic potential against in vitro and in vivo tumor cells models. These cellular effects of biflorin are dependent on its concentration. In addition to these activities, biflorin has been shown to be efficacious and safe, as it has no mutagenic potential. Biflorin can thus be considered a new prototype substance with potential anticancer activity. Further studies of this substance isolated from the roots of C. biflora L., however, are necessary.

\section{ACKNOWLEDGMENTS}

The support received from CNPq (Conselho Nacional de Desenvolvimento Científico e Tecnológico), CAPES (Coordenação de Aperfeiçoamento de Pessoal de Nível Superior) and FUNCAP (Fundação Cearense de Apoio ao Desenvolvimento Científico e Tecnológico, Brazil) to conduct this work is gratefully acknowledged.

\section{RESUMO}

A biflorina é uma $o$-naftoquinona com comprovados efeitos citotóxicos frente a células tumorais além de atividades antimicrobiana, antitumoral e antimutagênica. A biflorina é um composto isolado das raízes da planta Capraria biflora L. (Schrophulariaceae), originária das Antilhas e da América do Sul, que está localizada em zonas temperadas e tropicais. Este composto mostrou uma potente atividade contra microorganismos gram-positivos e bactérias álcool-ácido resistentes. Tem mostrado eficiência em inibir a proliferação celular em linhagens tumorais CEM, HL-60, B16, HCT-8, MCF-7. Recentemente, a linhagem tumoral SK-Br3 foi tratada com biflorina e 
demonstrou importante efeito citotóxico. Neste artigo, relatamos informações relacionadas com os primeiros estudos de caracterização estrutural, bem como os últimos relatos sobre a atividade biológica desta molécula.

Palavras-chave: Atividade biológica, Biflorina, Capraria biflora, produtos naturais.

\section{REFERENCES}

Acosta SL, Muro LV, Sacerio AL, Pena AR AND OKweI SN. 2003. Analgesic properties of Capraria biflora leaves aqueous extract. Fitoterapia 74: 686-688.

AlmeIdA ER, Silva-FILHo AAA, SANTos ER AND Lopes CAJ. 1990. Antiinflammatory action of lapachol. J Ethnopharmacol 29: 239-241.

Aquino TM, AMORIM ELC, LIMA CSA AND AlbUQUERQUe UP. 2001. Padronização Botânica de Capraria biflora L. (Scrophulariaceae). Acta Farm Bonaerense 20: 259-263.

Aquino TM, Lima CSA, AlbuQuerque UP AND AMORIM ELC. 2006. Capraria biflora L. (Scrophulariaceae): uma Revisão. Acta Farm Bonaerense 25: 460-467.

Asche C. 2005. Antitumor quinones. Mini-Rev Med Chem 5: 449-467.

Barbosa TP, CAMARA CA, Silva TMS, Martins RM, PINTO AC AND VARGAS MD. 2005. New 1,2,3,4-tetrahydro-1aza-anthraquinones and 2-aminoalkyl compounds from nor-lapachol with molluscicidal activity. Bioorg Med Chem 13: 6464-6469.

BEST WM AND WegE D. 1986. Intramolecular Diels-Alder additions of benzynes to furans. Application to the total synthesis of biflorin, and the mansonones E, I, and F. Aust J Chem 39: 647-666.

Carvalho AA, Costa PM, Souza LGS, Lemos TLG, Alves APNN, PESSOA C AND MORAES MO. 2013. Inhibition of metastatic potential of B16F10 melanoma cell line in vivo and in vitro by biflorin. Life Sciences 93: 201-207.

COMIn J, Gonçalves de Lima O, GRANT HN, JaCKMAN LM AND KELLERSCHIERLEIN W. 1963. Über die Konstitution des Biflorins, eines O-chinons der Diterpenreihe. Helv Chim Acta 46: 409-415.

Correia MP. 1984. Dicionário de Plantas Úteis do Brasil e das Exóticas Cultivadas. Instituto Brasileiro de Desenvolvimento Florestal. Rio de Janeiro, 1984.

Costa-Lotufo LV, Montenegro RC, Alves APNN, Madeira SVF, Pessoa C, Moraes MEA and Moraes MO. 2010. A Contribuição dos Produtos Naturais como Fonte de Novos Farmácos Anticâncer. Rev Virtual Quim 2: 47-58.

CRAGG GM AND NewMAN DJ. 2005. Plants as a source of anticancer agents. J Ethnopharmacol 100: 72-79.

DRISCOLL JS. 1974. Quinone structure-antitumor activity relationships. Cancer Chemother Rep 4: 3-4.

EHrLICH P AND HerTer CA. 1904. Over some uses of the naphtoquinonesulfonic acid. Zeitschrift fuer Physiologische Chemie 41: 379-392.
FErreira SB, GonZaGa DT, SANTOS WC, ARAUJo KGL AND FERREIRA VF. 2010. SS-Lapachona: Sua importância em química medicinal e modificações estruturais. Rev Virtual Quim 2: 140-160.

Fonseca AM, Pessoa ODL, SIlveira ES, Monte FJQ, BRAZ-FILHo R AND LEMOS TLG. 2003. Total assignements of ${ }^{1} \mathrm{H}$ and ${ }^{13} \mathrm{C}$ NMR spectra of biflorin and bis-biflorin from Capraria biflora Magn. Reson Chem 41: 1038-1040.

Forster PG, GHISALBERTI EL, JEFFERIES PR, POLETTI VM AND WHITESIDE NJ. 1986. The Chemistry of Eremophila spp. Phytochemistry 25: 1377-1383.

Gafner S, Wolfender JL, Nianga M, Stoecklievans H AND HosteTtMAnN K. 1996. Antifungal and antibacterial naphthoquinones from Newbouldia laevis roots. Phytochemistry 42: 1315-1320.

GonÇAlves de Lima O, D'AlbuQuerque IL, Loureiro P, CARMONA CL AND BERNARD MZ. 1954. Novas Observações Sobre a Biflorina, Antibiótico Isolado da Capraria biflora L. Rev Quím Industrial 249: 28-30.

Gonçalves de Lima O, D'Albuquerque IL, Maia D AND BORBA MA. 1961. A Ação da Luz Sobre a Biflorina. Rev Inst Antibiot 3: 97-100.

GonÇALVES DE Lima O, D'AlbuQuerque IL AND NAVARro MCP. 1962. Novo Método de Extração e Purificação da Biflorina com Possibilidade Industrial. Rev Inst Antibiot 1: 79-81.

GonÇAlves de Lima O, D'Albuquerque IL, Neto BM AND AlbuQuerQue MM. 1958. Breve Nota Sobre a Atividade Antimicrobiana da Biflorina Purificada por Partição Graig. Rev Inst Antibiot 1: 95-97.

GRANT HN, PRELOG V AND SNEEDEN RPA. 1963. Sinthese eines 1-oxa-phenalenderivatives mit dem Chromophoren System des Biflorins. Helv Chim 46: 415-421.

Gullo VP, McAlpine J, LAM KS, BAKer D AND PETERSEN F. 2006. Drug discovery of natural products. J Ind Microbiol Biotechnol 33: 523-531.

HALLIWELl B AND GUTTERIDGE JMC. 2007. Free Radicals in Biology and Medicine, $4^{\text {th }}$ ed., Oxford University Press, New York, $851 \mathrm{p}$.

HARVEY AL. 2008. Drug Discov Today 13: 894.

Hoppe IW. 1960. The x-ray crystallographic analysis of the constitution of biflorin (C20H20O3) Zeitschrift fuer Kristallographie, Kristallgeometrie, Kristallphysik, Kristallchemie 114: 393-409.

KIRKPATRICK P. 2002. Stitching together naturally. Nature Reviews Drug Discovery 1: 748.

LIU KC, LI J AND SAKYA S. 2004. Synthetic approaches to the 2003 new drugs. Mini Rev Med Chem 4: 1105-1125.

LYRA JÚNIOR DP, LIRA AAM, AQUINO TM, SOARES LAL AND SANTANA DP. 2007. Development and validation of Chromatographic Method for the Determination of Biflorin obtained from Capraria biflora Roots. Lat Am J Pharm 26: 125-129.

MANN J. 2002. Natural products in cancer chemotherapy: past, present and future. Nat Rev Cancer 2: 143-148. 
Matos Brito AE, Da Costa MS And Handro W. 1994. Rev Bras Fisiol Veg 7: 171-174.

McCowen MC AND StOnE RL. 1953. Eli Lilly Research Records. 18.953, Indianápolis.

Montenegro RC, Burbano RR, SILVA MN, LEMOS TG AND VASCONCELLOS MC. 2013. Biflorin, a naphthoquinone, inhibitsegfr in breast cancer cells. Med Chem 3: 179-182.

Moura KCG, EMERY FS, NEVES-PINTO C, PINTO MCFr, DANTAS AP, SALOMÃo K, DE CASTRO SL AND PINTO AV. 2001. Trypanocidal Activity of Isolated Naphtoquinones from Tabebuia and Some Heterocyclic Derivares: A Review from an Interdisciplinary Study. J Braz Chem Soc 12: 325-338.

Ndi ChI P, SEMPLE SJ, GRIESSER HJ, PYKe SM AND BARTON MD. 2007. Antimicrobial Compounds from the Australian Desert Plant Eremophila neglecta. J Nat Prod 70: 1439-1443.

Newman DJ AND CRAGG GM. 2007. Natural products as sources of new drugs over the last 25 years. J Nat Prod 70: 461-477.

Newman DJ, CRAGG GM AND SNADER KM. 2003. Natural products as sources of new drugs over the period 19812002. J Nat Prod 66: 1022-1037.

Pinto CN, Dantas AP, DE MOURA KCG, EMERy FS, Polequevitch PF, PINTO MCFR, DE CASTRO SL AND PINTO AV. 2000. Chemical reactivity studies with naphthoquinones from Tabebuia with anti-trypanosomal efficacy. Arzneim Forsch Drug Res 50: 1120-1128.

Prelog V, Gonçalves De Lima O AND Keller-Schierlein W. 1958. Über das Biflorin. Helv Chim Acta 41: 1386-1390.

SANTOS AF, FERraz PAL, PINTO AV, PINTO MCFR, GOULART MOF AND SANT'ANA AEG. 2000. Molluscicidal activity of 2-hydroxy-3-alkyl-1,4-naphtoquinones and derivatives. Int J Parasitol 30: 1199-1202.

Silva MN, Ferreira VF AND DE SOUZA MCBV. 2003. Um panorama atual da química e da farmacologia de naftoquinonas, com ênfase na $\beta$-lapachona e derivados. Quím Nova 26: 407-416.

SILVA P. 2006. Farmacologia. $7^{\mathrm{a}}$ ed., Guanabara Koogan, Rio de Janeiro.

Simões CMO, Schenkel EP, Gosmann G, Mello JCP, MENTZ LA AND PETROVICK PR. 2001. Farmacognosia: da planta ao medicamento. $3^{\text {a }}$ ed., Editora da Universidade UFRGS/Editora da UFSC, Porto Alegre/Florianopolis.

SONG YS AND LEE K. 2009. A new synthetic route to $2 \mathrm{H}$-benzo[g]chromene-5,10-diones involving ring closing metathesis. J Heterocyclic Chem 46: 207-221.
STAGLIANOKWETAL. 2006. Regiocontrolled synthesis and HIV inhibitory activity of unsymmetrical binaphthoquinone and trimeric naphthoquinone derivatives of conocurvone. Bioorg Med Chem 14: 5651-5665.

TEIXEIRA MJ, Almeida YM, Viana JR, Holanda Filha JG, Rodrigues TP, Prata JR JRC, COElho ICB, RaO VS AND POMPEU MML. 2001. In vitro and in vivo Leishmanicidal activity of 2-hydroxy-3-(3-methyl-2butenyl)-1, 4-naphthoquinone (lapachol). Phytother Res 15: 44-48.

THOMSON RH. 1987. Naturally Occurring Quinones III: Recent Advances, Chapmann and Hall, New York.

Tseng CH, Cheng CM, Tzeng CC, Peng SI, Yang CL AND CHEN YL. 2013. Synthesis and anti-inflammatory evaluations of $\beta$-lapachone derivatives. Bioorg Med Chem 21: 523-531.

VASCONCELLOS MC, BEZERRA DP, FONSECA AM, ARAUJO AJ, Pessoa C, Lemos TL, Costa-Lotufo LV, Moraes MO AND Montenegro RC. 2011. The in-vitro and in-vivo inhibirtory activity of biflorin in melanoma. Melanoma Res 21: 106-114.

VAsconcellos MC, Bezerra DP, Fonseca AM, PEREIRA MR, Lemos TL, Pessoa OdL, Pessoa C, Moraes MO, Alves AP AND CostA-LotUfo LV. 2007. Antitumor activity of biflorin, an o-naphthoquinone isolated from Capraria biflora. Biol Pharm Bull 30: 1416-1421.

VASCONCELLOS MC ET AL. 2010. Evaluation of the cytotoxic and antimutagenic effects of biflorin, an antitumor 1,4 o-naphthoquinone isolated from Capraria biflora L. Arch Toxicol 84: 799-810.

VAsconcellos MC, Montenegro RC, Militao GC, FonseCA AM, Pessoa OdL, Lemos TL, Pessoa C, Moraes MO AND Costa-LotUfo LV. 2005. Bioactivity of biflorin, a typical o-naphthoquinone isolated from Capraria biflora, L. Z. Naturforsch C 60: 394-398.

ZAKHAROVA OD, OVCHINNIKOVA LP, GORYUNOV LI, Troshkova NM, SHTEINGARTS VD AND NEVINSKY GA. 2011. Cytotoxicity of new polyfluorinated 1,4-naphtoquinones with diverse substituents in the quinone moiety. Bioorg Med Chem 19: 256-260.

Zani CL, Chiari E, KretTli AU, MurTa SMF, CunNingham ML, Fairlamb AH AND ROMANHA AJ. 1997. Antiplasmodial and anti-trypanosomal activity of synthetic naphtha[2,3-b]thiopen-4,9-quinones. Bioorg Med Chem 5: 2185-2192. 